\title{
The Bad Effects Caused by Policy Prescription and Financial Assistance by IMF on Developing Countries
}

\author{
Shabikunnahar Bonna* \\ Department of Economics, Jatiya Kabi Kazi Nazrul Islam University, Trishal, Mymensingh, Bangladesh. \\ *Correspondence: bonnashabikunnahar@gmail.com (Shabikunnahar Bonna, Lecturer, Department of Economics, Jatiya \\ Kabi Kazi Nazrul Islam University, Trishal, Mymensingh, Bangladesh).
}

\begin{abstract}
Actually in some cases the IMF has a little positive effects on developing economics while has a vast bad effect on all developing economics. The main purpose of the study is to examine the impact of IMF on developing countries. The globalization of the world economy gives rise to large global inequalities. The inequalities are responsible for increasing absolute poverty and starvation. Low income countries are suffering from financial crisis to reduce its absolute poverty and starvation. So they have to depend on IMF and various financial institutions. But the IMF policies are heavily criticized and unhelpful. The IMF sometimes led to increased dependency of developing countries upon developed countries. The social sectors of developing countries such as health and education sectors are most affected by these policies. So these policies increase poverty and underdevelopment of developing world.
\end{abstract}

Keywords: Developing countries, IMF, SAPs, Policy, Conditionality and Crisis in developing countries.

\section{INTRODUCTION:}

The IMF, the World Bank and the World Trade Organization are main actors in the international political economy. The IMF and World Bank were created after $2^{\text {nd }}$ World War to assist the world economy for reconstruction and international cooperation in managing financial crisis. A significant role has been played by the International Monitory Fund (IMF) to construct the world economy, when the World War II was about to finish. The International Monetary Fund has emerged under increased scrutiny and attack, with some of the most intense criticisms aiming on the link between its programs and reduced economic growth in borrower countries (Dreher, 2006). From 1986 the IMF Structural Adjustment Facility Program has been focused on criticism. IMF's program and policy effectiveness has a lot of evaluation studies. The IMF provided financial assistance for many developing, developed and under developed countries.
Developing countries, here and many other literatures in economics are those countries characterized by low levels of living standards and other development drawbacks. They are always found in Asia, Africa, Middle East, Latin America, Eastern Europe and the former Soviet Union (Muhumed and Gaas, 2016). But the economic effects of IMF assistance have a lot of controversial debate. The findings of this debate are disappointing.

The conditions that IMF imposes on financial aid to poor countries are unnecessary. The possible negative effects that literature highlights are Moral Hazard problem and Dutch Disease. The IMF financial assistance and insurance are similar in nature. By taking this assistance the countries engage in conditional and unsound policies.

\section{Literature review}

In 1980, the Overseas Development Institute (ODI) conducted a research that states the criticisms of IMF. This report also supports the analysis which is 
considered as a pillar of what activist Titus Alexander calls global apartheid. In 2006, Action Aid policy analyst Akanksha Marphatia stated that any possibility of meeting the Millennium Development Goals (MDGs) in Africa was undermined due to the policy restriction imposed by IMF. The former Romanian Prime Minister Calin Popescu-Tariceanu claimed in his interview (2008-05-19) that 'since 2005, IMF is constantly making mistakes when it appreciates the country's economic performances'. Raghuram Rajan, the former chief economist of IMF and former governor of Reserve Bank of India (RBI), predicted financial crisis of 2007-08 as well as he criticized IMF's side line player behavior to the developed world. In 2009, Rick Rowden in his book titled 'The Deadly Ideas of Neoliberalism' mentioned that IMFs monetary approach of prioritizing price stability and fiscal restraint was unnecessarily restrictive to prevent the developing countries long term investment in public health infrastructure, quality improvement of public health and fight against AIDS (Mujeri et al., 2021). This was published by IMF's research department in 2016. The report stated that the organization has been 'overselling' restrictive fiscal policies, which they claim, has enhanced both financial crisis and world's economic inequality.

\section{Objectives of the study}

This article critically examines the IMF impact on developing countries. It concerns about developing countries because the IMF policies led to increase dependency of developing countries upon developed countries. IMF hurts mainly emerging markets economy, such as Argentina, Mexico, Brazil and other countries whose economies are emerging from financial stagnation. IMF policies have always hard up the developing countries in favor of the interest of global companies, that get benefits from deals and conditions that IMF imposes. Because of IMF structural adjustment programs, the international bankers have been gradually bankrupting the developing countries in order to buy their natural resources and small industries. The IMF is a developed country's tool for further development but imposing neocolonialist economic exploitation on the developing countries.

\section{METHOLODOGY:}

In the article, the secondary data have been used. Secondary data have been collected from concerned books, published Journals, daily newspapers, internet and other materials.

\section{A brief history of IMF}

IMF a specialized agency of United Nations (UN) founded at the Bretton Woods Conference in 1944. It was formed in 1945 with 29 member countries. Now there are total 189 countries are the member of IMF. The Headquarter of IMF is in Washington D.C. USA. The main purpose of IMF is to simplify international trade, ensure sustainable economic growth and overcome the balance of payment difficulties. IMF works to improve the economic situation of member countries. Besides this main purpose IMF provides advice and policy prescription to manage balance of payment difficulties. There are two major sources of IMF funds: quotas and loans. Quota generates most of the IMF funds. Economic and financial importance in the world derives the quota of member countries. Countries with larger economic importance have large quotas. The IMF is governed distinctively by an executive board that consists of its member countries, with having high weight ranking countries that provides more money to its Fund. This executive board sets board policies and approves loans for its member countries. To get voting power each member country is required to contribute funds according to its economic size and strength. In proportion to their contribution in funding, nations are awarded votes which determine the overall policy of the institution. At the time of setting up board policies, member countries' voting right to the IMF is weighted. That means the country which has bigger money contribution to IMF's fund distinctively possesses a higher voting power and having more say. The United States of America has the largest shareholder at the IMF maintaining vote power over major decisions at the IMF Fund.

\section{The following Table analyses which countries and blocks of countries have the largest voting power}

From the Table 1 we can see that the voting right for Rest of World is $31.9 \%$ where United States belongs itself $20.60 \%$. On the other hand, All of Europe possesses $30.40 \%$ voting power. As the voting power mostly concentrated to all developed countries so at the time setting up any policy and its implementation, developing countries will try to take favor after their own interest and the bitter experience is same like this. In this modern civilization this type of immoral voting weight ranking is really a hurtful 
matter. This type of practice gives a sovereign power to some specific member countries which leads them to influence all the policies in favour of them. Consequently, all the developing countries as member of IMF with having lower voting power are being deprived from various developmental projects even in some cases being badly affected by some Policies prescribed by IMF for them.

Table 1: Voting Power.

\begin{tabular}{|c|c|}
\hline Country & Voting (\%) \\
\hline United States & $20.6 \%$ \\
\hline All of Europe & $30.4 \%$ \\
\hline European Union & $24.5 \%$ \\
\hline Asia & $9.9 \%$ \\
\hline Latin America & $7.2 \%$ \\
\hline Rest of World & $31.9 \%$ \\
\hline
\end{tabular}

Source-http://web.stanford.edu/class/e297c/trade_environment/ global/hcrisis.html

\section{Financial Assistance and Policy Conditionality of IMF}

The IMF strengthened its support to its low income member countries to cope up with the changing economic conditions of these countries. IMF introduces some new lending instruments to assist its member countries directly and emergency basis. The IMF concentrates on making up balance of payment problem by providing on condition loans and advising stable exchange rate policy. The IMF has created modern day colonialism by 'Structural Adjustment Policies (SAPs)'. Structural Adjustment Policies (SAPs) of IMF and World Bank secure debt repayment requiring low income debtor countries to reduce their expenditure on education \& health, cut out basic food and transportation subsidies, devalued national currencies to make export cheap, privatize national assets and stagnate worker's wages. Such belt-tightening policies enhance poverty, shorten countries ability to develop domestic economics, increase malnutrition and give chance to multinational corporations to exploit their workers on low wages and their working environment. In 2010, IMF has established a Poverty Reduction and Growth Trust to make its financial support more flexible and tailored to the diversity of low income countries. Which has three concessional lending windows:

The Extended Credit Facility (ECF) - This instrument provides sustained engagement over the medium to long term lending facility to solve the balance of payment problems.
The Standby Credit Facility (SCF) - This instrument provides financing to its low-income member countries with actual short-term balance of payments.

The Rapid Credit Facility (RCF) - This window provides rapid financial support without strong conditionality for low-income countries facing urgent balance of payments needs. To give financial assistance IMF sets a condition. The funds are withheld if the conditions are not full filled. Some of the IMF conditions are as follows:

- Cutting expenditures

- Focusing economic output on direct export and resource extraction

- Devaluation of currencies

- Trade liberalization

- Increasing the stability of investment

- Balancing budget and not over spending

- Removing price control and state subsidies

- Privatization of state owned enterprises

- Enhancing the rights of foreign investors

- Improving governance and fighting corruption

IMFs experts seen BOP deficit as cost by a surplus money supply over the demand for it. So the essential task of IMF team is to restrict credit to remove BOP difficulties. Due to credit control, programs try to reduce government budget deficit. IMF team thinks exchange rate is an important influence on BOP. So it's all programs involves devaluation. IMF team gives attention how government reduces budget deficit by installing social safety net programs and reducing military spending.

At the same time, it gives importance on privatization policy. Because of many cases privatization of public enterprise reduces budgetary pressures but increase productivity. The Meltzer Commission, a leading critic, argues that the IMF was ineffective and inefficient, and was in need of a reform (Bird, 2007). Conditionality was also perceived as excessive (Bird, 2004). Facing these criticisms, the IMF started a reassessment of its programs and is trying to establish a medium-term strategy (Yang, 2013).

\section{Impact of IMF structural adjustment programs} and the debt burden in developing countries

For obtaining lower interest rates or getting new loans SAPs are policies. To ensure debt repayment 
and restructuring economic situation SAPs has forced developing countries to reduce expenditure in health, education. For IMF debt repayment policies is more important than developing countries development. When developing countries of South including those in East Africa affecting financial problem and take loan from IMF, these countries having no voice in decisions made against them. The financial assistance hampers the democratic process by imposing policies. This policy threatens nation's sovereignty. IMF policies include impact on state sovereignty, agriculture, exploitations of raw materials, education, environment, health, etc. The debt burden has continued to increase. Stieglitz has noted that world economy from Argentina to Moldova from Africa to Indonesia debt poses a severe problem for developing countries. The consequences of debt sometimes create debt crisis. Generally, money flows from rich country to poor country but some years later when debt repayment period comes a large amount of fund flow from poor to rich countries. Currency devaluation measures of developing countries increase export and reduce the value of domestic goods. Devaluation makes their goods cheaper for foreigners to buy and theoretically makes foreign inputs more expensive (Githua, 2011). Liberalization of trade and investment and high interest rate attract foreign investment and because of higher competition domestic banking system fails. Government reduces of spending reduce consumption and remove financial regulation, for this reason labor demand reduce and create unemployment problem, capital flows at increasing rate that cause social unrest. Investor concerns about their assets and pullout their assets. Pullout of assets can lead to economic collapse.Poverty reduction programs of the World Bank and the IMF are conditional on civil society's participation in the formulation and implementation of the national development strategy, their democratic record is particularly interesting to examine (Michaelowa \& Hänny, 2010). The IMF structural adjustment program has cost underdevelopment of developing countries.

\section{Criticism of IMF Policies}

Critics claim that IMF programmes and the conditionality they embody do not work, either because they are badly designed or because they are not fully implemented (Killick, 2004a, 2004b; Collier et al., 1997). They claim that IMF programmes have a negative effect on economic growth and on income distribution (Bird, 2004). The facilities that IMF provided are in form of standbys, extended arrangements, and structural adjustment facilities and enhanced structural facilities. IMF loans facilities are associated with some conditions like, decreasing budget deficit, devaluation, decreasing domestic credit expansion, unbinding controlled prices and interest rate, decreasing trade barriers and privatization of state enterprises. For balancing budget, the IMF recommends the loan receiver countries to raise taxes, to cut government spending. As a result, government reduces the expenditure on education, health and social care. According to UNICEF, as a result of debt crisis and IMF SAPs management over 500,000 children less than 5 years are died in each year in Africa and Latin America in late 1980s (Githua, 2011).

Despite its great and good objectives, the IMF suffers from some criticisms as follows:

\section{- Too much or too little intervention: The IMF} has been criticized for not reaching or for overreaching. It has been criticized for too cool or too excited to help defecting national policies. Since the US, Japan and Great Britain properly remarkable in IMF policies, it has been blamed of being a tool free market countries only. Thus free market supporter countries also criticized the IMF for too much intervention.

- Create Moral Hazard: Some member counties, like, Italy and Greece have been blamed of purchasing unstable budget because they believed that the IMF would come to their rescue. This is no different than moral hazard problem.

- Dutch Disease hypothesis: This hypothesis points out that, because of IMF assistance countries get a large inflow of foreign currency. Which may appreciate their local currency and they undermine their competitiveness in international market.

Furthermore, some other criticisms as follows:

- Low income countries have a less dominant role and control over IMF than developed countries.

- IMF assumes that all payments disequilibrium of low income countries was cost domestically. But United Nations Conference on Trade and Development (UNCTAD) accused that disequilibrium is external. 
- Some policies of IMF may not be helpful for development, because the deflationary effects of IMF policies led the low income countries to reduce of output and employment.

- IMF's role as generalist institution especially in macroeconomic issues needs reform because countries faces increased income inequality who takes assistance from IMF program.

- The borrowing countries economy is controlled by the IMF and its experts. IMF is the new form of colonization for debtor countries.

- Because of the reduction of fund from public health service demoralization are created in working place and brain drain of medical personnel occurs.

- Many of the programs of IMF breakdown because of adverse external developments. Because of insure financing, natural calamities such as drought and hurricanes countries get into difficulties.

\section{CONCLUSION:}

The developing countries are uncertain about the degree of impacts of adjustment policy. Financial assistance for meeting crisis situation of developing countries creates debt burden further more. Structural Adjustment Programs (SAPs) imposed by IMF provided loan and this load is disaster for developing countries. SAPs are simply a policy to remove all kinds of trade restrictions. In developing countries, the adjustment policies create slow growth, higher poverty, lower incomes, rising debt burden, low human development indicators. The policies proposed by IMF severely affect poor and middle income countries and these policies led to higher poverty and income inequality. On the contrary the countries such as Turkey and Malaysia, who rejected the policies, did very well. The economic growth is retarded by the IMF loan facility and it raises the gap between rich and poor. In many times this institution leads to economic stability. By imposing policies against the recipient countries willingness IMF loan facility weaken the economic freedom and sovereignty of those countries. In terms of documents and information the IMF has little transparency. There is also criticism in ineffective operations and corruptions. The IMF policies serve interest to the developed countries and hurt the developing countries. It is high time for developing countries to consider more financial alternative. They should develop and engage alternative financial institution to stop 80 years domination of IMF. The New Development Bank established by BRICS countries in 2014 is one of the available alternatives. In addition to the already existing regional development banks, launching the Asian Infrastructure Investment Bank (AIIB) may also balance the western domination. These institutions will give developing countries the chance to handle their own issues, rather than depending on the west (Muhumed and Gaas, 2016).

\section{ACKNOWLEDGEMENT:}

First of all, the author would like to thank the almighty Allah who gave her the energy and good health to undertake this study. The author is also thankful to reviewers and editor for their helpful comments and suggestions.

\section{CONFLICTS OF INTEREST:}

The author declares no conflict of interest.

\section{REFERENCES:}

1) Bird, G. (2004). The IMF and poor countries: towards a more fulfilling relationship. University of Surrey, unpublished.

2) Bordo, M.D. (2007). The Bretton Woods International Monetary System: A Historical Overview. University of Chicago Press. pp. 3-108. https://core.ac.uk/download/pdf/6899758.pdf

3) Collier, P. and Gunning, J.W. (1999). The IMF's role in structural adjustment. The Economic Journal, 109(459), pp.634-651.

https://onlinelibrary.wiley/

4) Dreher, A. (2006). IMF and economic growth: The effects of programs, loans, and compliance with conditionality. World Development, 34(5), pp.769-788.

https://econwpa.ub.uni-muenchen.de/econ-wp/ if/papers/0404/0404004.pdf

5) Fidrmuc, J. and Kostagianni, S. (2015). Impact of IMF assistance on economic growth revisited, 8(3), pp. 32-40. http://doi.org/10.14254/2071-789X.2015/8-3/2

6) Githua, D.W. (2013). The impact of International Monetary Fund (IMF) and the World Bank structural adjustment programmes in developing countries, Case study of Kenya (Doctoral dissertation).

7) Lang, V. (2020). The economics of the democratic deficit: The effect of IMF programs on 
inequality. The Review of International Organizations, pp.1-25.

https://link.springer.com/article/10.1007/s11558020-09405-x

8) Michaelowa, K. and Hänny, S.M. (2010). The impact of World Bank and IMF programs on democratization in developing countries. https://ethz.ch/content/dam/ethz/special-interest/ gess/cis/cis-dam/Research/Working_Papers/WP _2010/2010_WP62_Limpach_Michaelowa.pdf

9) Muhumed, M.M. and Gaas, S.A. (2016). The World Bank and IMF in Developing Countries: Helping or Hindering? World, 28(4), pp.237-249.

https://www.researchgate.net/publication/312320 $\underline{679}$
10) Mujeri N, Mustafiz S, Sanjida SMTJ, and Zulkarnine A. (2021). Foreign direct investment in Bangladesh: analysis of policy framework, impact and potential, Int. J. Manag. Account. 3(3), 60-82. https://doi.org/10.34104/ijma.021.060082

11) Yang, G. (2013). Evaluate the Effect of IMF's Longer-Term Concessional Lending Programs on Growth in the Development Background of Sub-Saharan Region. Undergraduate Economic Review, 10(1), p.2.

https://pdfs.semanticscholar.org/e9a7/195c118e0 e18e2e5b244328d9ae21c21a3d5.pdf

Citation: Bonna S. (2021). The bad effects caused by policy prescription and financial assistance by IMF on developing countries, Asian J. Soc. Sci. Leg. Stud., 3(5), 172-177.

https://doi.org/10.34104/ajssls.021.01720177 (c) $\underset{\mathrm{Er}}{\mathbf{P}}$ 